\title{
UNIVERSITYOF
}

FORWARD

THINKING

WESTMINSTER用

WestminsterResearch

http://www.westminster.ac.uk/westminsterresearch

Bumped Redundancy and the Range of Reasonable Responses:

To what Extent, if any, should Employers Consider Bumping?

Life after Mirab v Mentor Graphics Limited UKEAT/0172/17DA

Singh, $C$.

This is a copy of the final version of an article published in Issues in Legal Scholarship, DOI: 10.1515/ils-2019-0007.

It is available from the publisher at:

https://dx.doi.org/10.1515/ils-2019-0007

The WestminsterResearch online digital archive at the University of Westminster aims to make the research output of the University available to a wider audience. Copyright and Moral Rights remain with the authors and/or copyright owners.

Whilst further distribution of specific materials from within this archive is forbidden, you may freely distribute the URL of WestminsterResearch: ((http://westminsterresearch.wmin.ac.uk/)).

In case of abuse or copyright appearing without permission e-mail repository@westminster.ac.uk 


\title{
Charanjit Singh ${ }^{1}$
}

\section{Bumped Redundancy and the Range of Reasonable Responses: To what Extent, if any, should Employers Consider Bumping? Life after Mirab v Mentor Graphics Limited UKEAT/0172/17DA}

\author{
${ }^{1}$ University of Westminster, Westminster, UK, E-mail: Doctor.csingh@gmail.com
}

\begin{abstract}
:
Employers often face a plethora of issues in redundancy situations. Likewise, employees often fear or are overwhelmed by the prospect that they may be chosen for redundancy. Whilst these issues have been widely written about there is little discussion of "bumping." When the issue appears in the employment tribunal, in cases such as Mirab v Mentor Graphics Limited, it is too late and the employer faces a successful unfair dismissal claim against it. Bumping occurs where an employer makes redundant a junior employee: one whose role has not identified as being at risk of redundancy. The result is that the more senior employee, one whose role was been identified as being at risk of redundancy, is placed into the junior role and therefore becomes subject to terms and conditions that are often less beneficial for example the junior role will inevitably come with a reduction in salary and/or perks. This article explores the legal issues that surround the instances in which an employer should consider "bumping," its relationship with the band of reasonable responses and the resultant effect, if any, of failing to do so.
\end{abstract}

Keywords: band of reasonable responses test, bumped redundancy, employment/labour law, redundancy law, unfair dismissal

DOI: 10.1515/ils-2019-0007

Received: March 18, 2019; Accepted: March 26, 2019

\section{Introduction}

In this article the concept of "bumping"1 and the novel problems it poses will be explored with the aim of suggesting possible solutions to help employers navigate them and inform employees. The law on unfair dismissal and redundancy is fairly well settled, therefore some aspects of the law are briefly setout as a prelude to the discussion on bumping, and to provide context to the legal framework in which the practical reality of unfair dismissal and redundancy exist.

\section{The Tumultuous Employment Relationship}

The employment relationship exists in a rather fraught postmodern reality in that the very basis of the on-going employment contract is, more often that not, premised upon the fiction of permanency. Employers contend that regulation acts to stifle business and its ability to manage its operational needs. Employees argue that they need protection from scrupulous employers whose business needs would take precedence over their welfare. Collaterally, in the world-at-large and in modern-life "credit" 2 requires certainty or security of tenure to minimize the risk of default. There are a plethora of reasons that demonstrate how everyday lives rely on employment. Clearly, there is a balance to be struck between the interest of the employer with that of the employee and employment law in the United Kingdom (UK). Thanks to the jurisprudence of the UK courts, the willingness of the legislature and the European Union ${ }^{3}$, the Kingdom seems to have mostly navigated that need fairly successfully. 


\section{Unfair Dismissal}

Unfair dismissal ${ }^{4}$ is a statutory right that is available to employees who believe that their employer has either unreasonably or unfairly dismissed them ${ }^{5}$. Only an employee who has two years of continuous employment ${ }^{6}$ has the right to bring this claim, this is known the statutory qualifying period. There are of course exceptions to the requirement in some instances for example in relation to those dismissed for a reason relating to the enforcement of contractual or legal rights, membership or non-membership of a trade union or for conducting trade union activities ${ }^{7}$.

The law on unfair dismissal provides that an employer may dismiss an employee for one of five reasons; gross misconduct at work, redundancy, statutory requirement or illegality, a lack of capability or qualification to do the job or some other substantial reason.

The employer must prove, to the employment tribunal if the dispute ends up there, that (a) one of these reasons exists and (b) that it has acted reasonably when dismissing the employee for that reason. The Advisory, Conciliation and Arbitration Service (ACAS) Code of Practice on Disciplinary and Grievance will be taken into account by the employment tribunal to determine in fact whether the employer has acted reasonably when dismissing on the grounds of capability or conduct. The employer must also show that the decision to dismiss fell within a range of reasonable responses open to an employer premised on the evidence before it at the time in question, see Iceland Frozen Foods $v$ Jones $^{8}$.

In British Home Stores Ltd v Burchell ${ }^{9}$ the claimant, Burchell, was dismissed for allegedly being involved in acts of dishonesty along with a number of other employees. These acts related to irregularities connected to staff purchases. BHS conducted an investigation into the allegations during which Burchell was implicated by one of the others involved. On appeal the EAT held that Burchell had not been unfairly dismissed and applied the range of reasonable responses test, the EAT also provided guidance for the approach that ETs should take in cases involving misconduct as follows, an employer must:

- Demonstrate that it believed the employee was guilty of the misconduct at the time it made the decision to dismiss;

- Demonstrate that it had in its mind reasonable grounds upon which such belief could be founded/sustained;

- At the final stage at which it had formed a belief on the grounds it had in its mind, must have carried out a reasonable amount of investigation ${ }^{10}$ in all the circumstances of the case.

This is referred to as the band of reasonable responses test. Per the jurisprudence of the English courts this is a test of reasonableness and not one of perversity ${ }^{11}$. In West Midlands Co-operative Society Ltd $v$ Tipton ${ }^{12}$ Lord Bridge set out "the crucial question: did the employer act reasonably or unreasonably in treating the real reason as a sufficient reason for dismissing the employee"13.

Judicial guidance on the application and definition of s.98(4) of the Employment Rights Act 1996 (ERA) is not just settled but familiar to employers and lawyers alike. These are as follows; when assessing whether or not an employer has acted reasonably in making a decision to dismiss the tribunal must consider the decision made against the set of objective standards of a hypothetical reasonable employer and not its own subjective views. The salient question is whether the employer has acted within "a range or band of reasonable responses" in terms of the employee's misconduct. Thus, to be unreasonable a decision to dismiss does not need to be perverse. On deciding whether or not a dismissal was fair or unfair the ET will not substitute its own view for that of the employer.

In terms of compensation the three remedies available to a successful claimant are: reinstatement, reengagement or compensation ${ }^{14}$. The latter of the three is most common, either by negotiation or resultant design, given that the employment relationship will usually have irretrievably broken down.

\section{Redundancy}

Redundancy is one of the five potentially fair reasons to dismiss an employee under UK employment law. Employees that are employed for two years continually ${ }^{15}$ and who are fairly dismissed by reason of redundancy are entitled to a redundancy payment ${ }^{16}$, notably equivalent to the basic award in cases of unfair dismissal compensation.

Section 139(1)(a)(i)-(ii) and (b)(i)-(ii) of the ERA 1996 defines redundancy as “... [dismissal that] ... is wholly or mainly attributable to ... the fact that his employer has ceased or intends to cease ... to carry on the business for the purposes of which the employee was employed by him, or ... to carry on that business in the place where 
the employee was so employed, or ... the fact that the requirements of that business ... for employees to carry out work of a particular kind, or ... for employees to carry out work of a particular kind in the place where the employee was employed by the employer, have ceased or diminished or are expected to cease or diminish"17.

In deciding whom to make redundant an employer must undertake a proper process in (a) choosing an appropriate poo ${ }^{18}$ of employees at risk of redundancy and (b) applying a fair and proper procedure to them to determine selection. In terms of the latter the employees must be graded according to their abilities, aptitude for work, attendance record, disciplinary record, performance, skills, time keeping amongst other objective criteria. As part of the selection process the employer should consider suitable alternative employment that may be offered to the employees selected. A failure to do so may amount to an unfair dismissal. When considering suitable alterative employment an employer may be obliged to consider roles that are not available or vacant because someone else is in that job role. This is known as "bumping" and thus a bumping redundancy occurs when an employee whose role is not at risk of redundancy is made redundant and then their post filled by an employee whose role had become redundant. A dismissal in this instance will still be by reason of redundancy. This is discussed further below at 3.2.

Application of the criteria must be evidenced (see British Aerospace PLC v Green [1995] ${ }^{19}$ ). Finally, employers that are seeking to make 20-99 employees redundant must undertake meaningful consultation; a failure to do so could result in a finding of unfair dismissal ${ }^{20}$ - a discussion of the process is beyond the scope of this article.

An employee who has been continuously employed for a minimum of two years will be entitled to a statutory redundancy payment ${ }^{21}$ from their employer. Often employers will have generous contractual redundancy schemes in the contract of employment or there is custom and practice of them having provided enhanced payments: both may lead to a greater payment than that available under the statutory scheme. Employees can lose the right to a payment where the employee has unreasonably rejected suitable alternative employment or where the employee obtains a new job and wishes to leave before the employment is due to end ${ }^{22}$.

\section{Bumped Redundancy ${ }^{23}$}

It was mentioned earlier that an employer when considering suitable alterative employment might be obliged to consider bumping. The purpose of a bumping redundancy is to retain more skilled and experienced employees. In particular cases an employer might be obliged to consider this option to ensure dismissals are fair. Case law provides notable evidence of the fact that the ET and EAT have held that in some instances it is unfair not to consider bumping a more junior employee, this stands firm even where the employee whose job is at risk of redundancy intimates that they would not be willing to accept a more junior role.

The factors that affect the imposition of an employer's obligation to consider bumping rests a variety of factors including differences in the two roles: including benefits/perks and salary, the qualifications held by would take a voluntary redundancy. The problem posed stems from the fact that there were no fixed rules on whether an employer should or should not consider bumping. For instance, it was unclear whether the employee who is at risk of redundancy had to intimate to his or her employer that they would consider a more junior role. If so, when should this be done; during consultation meetings or at some other point and collaterally when is it too late to intimate this.

The most salient of these questions has been put to rest by the decision of the EAT in Mirab v Mentor Graphics Limited $^{24}$. In this case the claimant was a Sales Director whose role had become redundant. The ET had been satisfied that this was a genuine redundancy for the purposes of s.139 of the ERA 1996 and thus constituted a potentially fair reason to dismiss per s.98 of the same Act. In determining whether the dismissal was fair as required by s.98(4) of the ERA 1996 the ET had found that the employer (respondent) had acted sufficiently in looking for suitable alternative employment. It also found that the employer was not required to consider bumping any other employee who was working at the subordinate Account Manager level (there were no other Sales Directors) because this obligation only arose when an employee him or herself raised it. The claimant had on many occasions expressed the view, to his employer that if he were treated as an Account Manager (a role subordinate to a Sales Director) he would consider this as a constructive dismissal. The ET found that placing the claimant in a pool on his own, given he was the only Sales Director, rather than with other Account Managers firmly fell within the range of reasonable responses.

During the consultation meetings, the claimant had stipulated that he had not considered any of the other offers of suitable alternative employment the employer had provided him with but had suggested that an Account Manager should be made redundant rather than him. The employer argued that it believed that this was not an intimation that the claimant wished to be considered for and would be open to accept the subordinate role of Account Manager but that he should remain as Sales Director. The ET decided that given the claimant had not offered to take the subordinate role nor suggested bumping the employer was not under a legal obligation to consider it. 
The EAT disagreed; it was incorrect to come to this conclusion from the evidence and that the ET had erred in law when suggesting that the claimant had to raise bumping in order for an employer to consider such a course of action. The question, in law, is whether the employer's failure to consider bumping fell within the range of reasonable responses. On that basis the EAT remitted the case back to the ET for reconsideration. The EAT noted that "it would be [difficult] ... to suggest that the [employer] ... itself was bound to raise" bumping, the reason for this was as follows: (a) there were no vacant Account Manager roles at the time, (b) the claimant had failed to consider the offers of suitable alternative employment from the list the employer had provided him with and (c) the claimant had objected in the past to being treated as an Account Manager. The circumstances had been altered by the fact that the claimant had suggested for an Account Manager to be made redundant instead of him which, arguably, gave rise to an obligation for the employer to consider bumping.

The EAT confirmed that where an obligation to consider bumping arose, because an employee indicated they would take a subordinate role, the employer could still reject this on a reasoned basis. For instance, differences in salary, variation in qualifications requirements and even the fact that the employer would have to dismiss another employee to facilitate this. In each case the ET would be required to determine this.

\section{The Effect of the Decision in Mirab ${ }^{25}$ - Conclusion}

The decision, at the very least, means that employers should raise the issue of bumping during the redundancy process. Employers are well versed with the legal requirements, and documentation of, fair and objective selection criteria, the pool of candidates and of course consultation meetings. Thus, it would be advisable that employers as part of any consultation process should be discussing, with those identified as being at risk of redundancy and as part of any offer of suitable alternative employment, whether they would be willing to accept a subordinate role. The likelihood is that most employees would decline this, but where an employee indicates they would be open to this then the employer should consider bumping and raise relevant discussions with the employee regarding this. Even if at the end of that process the employer then rejects the idea as being inappropriate. Of course this will have to be documented and reasoned. Thus, in short the advice of the EAT in Mirab $^{26}$ is as follows:

a. There is no rule of law that an employer must always raise and consider bumping with an employee who is at risk of redundancy especially where the bumped role is one that is subordinate and paid less well [etcetera];

b. There is no rule of law that states that an employee who is at risk of redundancy must tell his or her employer that they wish to be considered for a subordinate role before their employer is obliged to consider bumping;

\section{c. A failure to consider bumping can result in potentially fair dismissal being rendered unfair; and \\ d. The question for the ET is whether the employer has acted within a range of reasonable responses.}

Therefore, employers would be well advised to answer the following question: have we acted within a range of reasonable responses? The costs of failing to do so could result in re-instatement or re-engagement with compensation, or a compensatory award given the dismissal is rendered unfair as discussed earlier in the article.

\section{Notes}

1 Although the exact etymology is unknown; the term bumping seems to take inspiration from the concept of gazumping in English property law. This is where a higher offer is made for a house than somebody whose offer the seller has already accepted and therefore succeeds in buying the property. The practice is contrary to the law of contract and illegal only at the point of 'exchange of contracts' - the point at which a legally binding contract comes into existence.

2 Note that credit here refers to the 'economic' rather than the moral or social, notably a reference to financial standing or creditworthiness linked to an individual's ability to obtain services (or goods) on a trust basis i.e. that payment will be made sometime in the future. This comes in the form of a contractual agreement whereby the individual will avail him or herself to a bank overdraft, personal loan, mortgage, credit card or agreement, on the basis that he or she will repay the 'lender' at some later date with consideration (interest). Credit is a necessary part of life and lenders will often only lend to those that pose low risk of default. Security of tenure reduces that risk and increases the likelihood that an individual has the ability to repay the credit. On credit and society see generally: Muldrew, C. (1998). The Economy of Obligation: The Culture of Credit and Social Relations in Early Modern England. London: Palgrave Macmillan.

3 Specific mention is made to the Transfer of Undertakings and Protection of Employment Regulations 2006 as amended by the Collective Redundancies and Transfer of Undertakings (Protection of Employment) (Amendment) Regulations 2014.

4 Employees also have the right not be constructively dismissed, as set out in Part X of the ERA 1996. It is defined in s.95 as (1) [a dismissal by an] ... employer [where] ... (c) the employee terminates the contract under which he [or she] is employed (with or without notice) in circumstances in which he [or she] is entitled to terminate it without notice by reason of the employer's conduct. The conduct required is 
set out in Western Excavating (ECC) Ltd v Sharp (1978) ICR 221 - the test is not one of the reasonableness or unreasonableness of the conduct, the questions the ET will ask are as follows: (a) did the conduct amount to a repudiatory breach of contract that went to the very root of the contract of employment or (b) did it demonstrate that the employer no longer wished to be bound by one or more of the essential terms within the contract of employment. In these situations the employee can treat him or herself as having been discharged from further performance therefore constructively dismissed and possibly entitled to compensation. For an example see: Coleman v SEW Baldwin [1977] IRLR 342 - in this case the employee successfully argued that that they had been constructively dismissed as a result of them having had some of their duties and responsibilities removed. See also: Land Securities Trillium Ltd $v$ Thornley [2005] IRLR 765 in which a change in job description that had the effect of deskilling an architect was held to amount to a constructive dismissal.

5 There are five fair reasons to dismiss an employee, these are: capability or performance, conduct, redundancy, statutory illegality and some other substantial reason.

6 Note that the statutory qualifying period has swung from 1 to 2 years and vice versa over the years. Therefore, there is some debate as to who should have the right to make this claim - does 2 years of continuous employment allow the employer greater flexibility to manage his or her workforce without a threat of litigation and does an employee who has worked for 2 years any more or less committed that one who has worked with the same employer for only 6 months. Thus, the period seems a politically charged fairly arbitrary period - even more so given the existence of automatic unfair dismissals etcetera. Perhaps the period should be completely abolished - a project on the impact on the tribunal system may have to be carried out as a policy consideration prior to any such 'drastic' change.

7 Other instances of automatic unfair dismissal are dismissals relating to: health and safety, bringing proceedings against an employer for the breach of employment rights, exercising the right to be accompanied at a disciplinary or grievance hearing, refusal to opt-out of the rights afforded by the working time directive, obtaining or preventing recognition of a workplace trade union, the enforcement of rights under the National Minimum wage Act, making a protected disclosure under the law on whistleblowing, participating in lawful industrial action (strike), requesting study or training, an employee's function as the trustee of a pension fund, refusing to work on a Sunday (shop workers) and an employee's right to adoption, maternity or paternity leave, time off for looking after dependents and the right to request flexible working.

8 [1982] IRLR 439.

9 [1978] IRLR 379.

10 An employer will not be able to avoid a finding of unfair dismissal it can show that (a) the decision fell into the range of reasonable responses and (b) that its failure to follow a fair and proper procedure would not have made a difference to the final decision. See: Polkey v. A.E. Dayton Services Ltd (1987) UKHL 8 - for a discussion in relation to the end of the 'no difference rule' that allowed employers to avoid liability.

11 Commentators have suggested that there is little conceptual difference between the 'band of reasonable responses test' and a 'perversity test' - the latter requires an overwhelming case to be made out, see Yeboah $v$ Crofton [2002] IRLR 634 at paragraph 93, as per Mummery LJ. If the former were required to do this too it would exclude many instances in which the ET could hold an employer to account that it lacked the severity required thereby limiting it to only the most extreme (perverse) cases. Neither would it be in accordance with the statutory language deployed within s.98(4). The problem is that it is often ambiguous to both academicians and lawyers alike as to exactly what the test requires. See also Tayeh $v$ Barchester Healthcare Limited [2013] EWCA Civ 29, Haddon v Van den Bergh Foods Ltd [1999] ICR 1150 and subsequently Foley $v$ The Post Office [2000] ICR 1283.

12 [1986] IRLR 112. Note: Turner v East Midlands Trains Ltd [2013] IRLR 107 - in this case there was some very mild suggestion that there may be more than one test as set out in s.98(4)(a)-(b) of the Employment Rights Act 1996.

13 It should be noted that the employment tribunal could adjust an award by increasing or decreasing it by $25 \%$ where it finds that either the employer or the employee has unreasonably failed to follow the ACAS code of practice. See also, regarding reductions for contributory fault, Nelson $v$ BBC (No. 2) [1997] IRLR 346.

14 Compensatory element of a compensation award for an unfair dismissal currently (capped statutorily) stands at $£ 83,682$, or 52 weeks gross salary - whichever is the lower of the two. This is in addition to the basic award that an ET may make is up to a maximum of $£ 15,240$. One of the most common deductions made from compensation is known as the Polkey deduction. It will apply where the employer has been found of unfairly dismissing an employee by failing to follow a correct procedure but where the employee would have been dismissed had a fair procedure been followed then the compensatory award can be reduced by up to $100 \%$. Figures correct as at 01.03 .2019 . Note authority: Polkey v. A.E. Dayton Services Ltd (1987) UKHL 8.

15 Section 155 Employment Rights Act 1996 (ERA). Note there are statutory rules in relation to continuity and attempts to break it, for instance where there is a short break of less than a week then statutory provisions allow for continuity to be preserved, see s.210(4) ERA 1996. On continuity generally ss.2011 - 219 ERA 1996.

16 Section 135 ERA 1996.

17 In Murray v Foyle Meats Ltd [1999] IRLR 56 the House of Lords decided that the ET must determine two questions of fact in terms of causation: (a) did one or another states of economic affairs exist and (b) was the dismissal attributable (caused) wholly or mainly to those states of economic affairs. This was a departure from the function and contract tests.

18 This would be one in which the job roles are interchangeable.

19 ICR 1006.

20 See E-Zec Medical Transport Service Ltd v Gregory [2008] UKEAT 0192081411 - this case concerns proper consultation and objective application of the criteria. On appeal by the employer the EAT held: 'that [the ETs] ... task was not to subject the marking system to microscopic analysis or to check that the system had been properly operated but ... to satisfy [itself] ... that a fair system was in operation. In our view [the ET was] entitled to come to the conclusions that this was not a fair system and that the appeal process did not cure it'. The case provides useful guidance to lawyers, trade union representatives and employers.

21 The statutory redundancy calculation uses (a) the length of service, (b) the employee's age and his or her weekly pay. The payment will based on $1 / 2$ week's pay for each complete year of employment when the employee was aged between 18 and 21, 1 week's pay for each complete year of employment when the employee was aged between 22 and 40 and 11/2 week's pay for each complete year of employment when the employee was aged between 41 and 64 . The gross weekly wage will usually be that at the point the redundancy occurs with a statutory cap of $£ 508$ as at the $6^{\text {th }}$ April 2018. This does not include overtime and where earnings fluctuate then an average over a 12-week period prior to the redundancy will be used. The maximum statutory redundancy payment is $£ 15,240$ as at 01.03.2019.

22 Redundancy is a form of dismissal and therefore the employee is still entitled to his or her statutory or contractual notice period.

23 Bumping redundancy is a term that many people are not familiar with and many of the textbooks on the subject fail to discuss this option.

24 UKEAT/0172/17DA.

25 See ibid. at p.9.

26 See ibid. at p.9. 


\section{Bionotes}

Dr. Charanjit Singh is a widely published barrister, academic and a certified civil and commercial mediator. He has built up extensive expertise in criminal evidence and his current research focuses on employment law, biometric and forensic evidence, terrorism and serious and organised criminality. Direct contact can be made on: Doctor.csingh@gmail.com. 